\title{
A Study on the Estimation of Flood Damage in Medan City
}

\author{
A. Perwira Mulia Tarigan ${ }^{1, *}$, Asril Zevri ${ }^{2}$, Rudi Iskandar ${ }^{1}$, and Ivan Indrawan ${ }^{1}$ \\ ${ }^{1}$ Department of Civil Engineering, Engineering Faculty, University of Sumatera Utara (USU), Medan, \\ Indonesia \\ ${ }^{2}$ Department of Civil Engineering, Engineering Faculty, Muhammadyah University of Sumatera \\ Utara (UMSU), Medan, Indonesia
}

\begin{abstract}
A large part of the Medan City, a city of more than 2 million people, experiences frequent floods which cost a lot of damage due to the inundation. The objective of this study is to estimate the area of inundation and the consequent damage cost with reference to the predicted discharges of the rivers crossing the city in a certain return period. Two main watersheds are involved here, i.e. the watersheds of Belawan and Deli.The relevant data for the flood estimation include rain fall, watersheds, as well as river profiles and cross-sections. The computed and mapped flood affected area is then stacked on top of the city maps in a GIS framework. By identifying the number of affected houses, the damage cost for a return period of flood can be estimated in a relative accurate manner. Also the affected city infrastructures can be shown and listed.
\end{abstract}

\section{Introduction}

There are two main watersheds, i.e. Belawan and Deli, which encompass Medan City within their river basins' areas of $417.63 \mathrm{~km}^{2}$ and $459.86 \mathrm{~km}^{2}$, respectively. A third watershed of Percut with a smaller basin of $194.88 \mathrm{~km}^{2}$ includes merely the eastern fringe of Medan.Both watershed have their headwaters in the hilly district of Deli Serdang located south of the Medan City's administrative area. The Belawan River in the west side and and the Deli River in the east side cross the city in northerly courses before they reach the straits of Malacca (Figure 1).

In a study supported by JICA (1992), it is reported that the inundation area in Medan City during the annual flooding may reach up to 9000 ha. A suggestion from the study was to construct a flood canal that diverted a portion of the peak discharge of the Deli River to the Percut River before its water entered the center part of Medan. The canal was the then built and completed in 2008. However, the flood has still been occuring each year. Meanwhile inevitably land use changes and upstream deforestation due largely to a population increase of $0.26 \%$ per year would definitely cause more intense and frequent flooding in recent years [7]. More intense and frequent flooding would ensuingly mean more innundatian area with more affected houses and infrastructures in the city of more than 2 million people. 


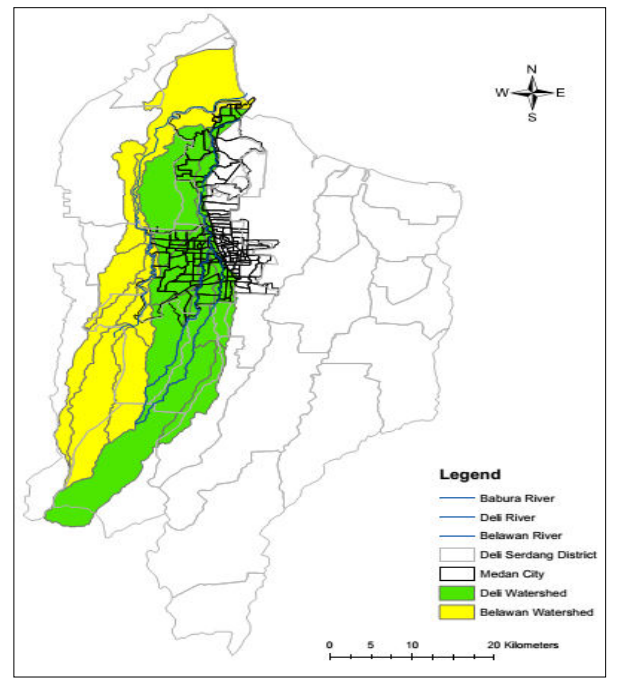

Fig. 1. Map of Medan City showing the watersheds of Belawan and Deli

Therefore it is of considerable importance to study the flood events and to estimate the resulting damage in the context of flood mitigation plan. The purpose of this study is to estimate inundation area and the consequent damage cost with reference to the predicted dischargesof the rivers in some certain return periods. The relevant data for the flood estimation include rain fall, watersheds, as well as river profile and cross-section.The resulting flood maps are to be stacked on top of the available city maps in GIS layers [9] [10] [12]. Hence by knowing the number of affected houses and infrastructures, the damage cost for a return period of flood is calculated in a relative accurate manner.

\section{Basic Assumptions}

Floods are an inevitable component of any river system, since runoff volumes vary and tend to increase substantially with time, especialy during the rainy season [1] [2] [7]. The precipitation within Belawan and Deli watershed in a year is tipically more than $2000 \mathrm{~mm}$ with the number of rainy days approximately the same as that of no rain days. The wet seasons in a year occur twice in a year, i.e. during March to May $(120-150 \mathrm{~mm}$ of rainfall per month) and September to December $(170-220 \mathrm{~mm}$ of rainfall per month) with the latter causing more intense and frequent flooding. Among others, [3] [4] [11] 14] have observed floods occurs in Medan City because high precipitation and large runoff during wet seasons in a year exceed the capacity of the river channels within the Belawan and Deli watersheds. This condition commonly take places especially in October until November when the the amount of rainfall likely exceed $200 \mathrm{~mm}$ in a month.

The capacity of the river channels vary across the city of Medan. The upper portions, which have not been normalized yet, have significantly smaller ones than the lower portion which has been normalized to protect more the city infratructures. Figure 2 shows a schematic picture of the capacity of the Deli River, whereas Table 1 tabulates the 10 to 100 years discharges at locations indicated in Figure 2 (JICA, 1992). It can bee seen that the capacity of the river can not accommodate even for 10 years flood of $Q_{1}, Q_{2}$, and $\mathrm{Q}_{3}$. It can also be understood that the annual flood is commonplace in certain portions of the river channels. 
It is a common practice to design a capacity of a primary drainage to sustain at least a 25 year flood flow. It is also a common practice to estimate flood events of a primary drainage like the river channel for at least 25 years recurrence interval. Hence in this study we focus our flood and damage cost estimation on the 25 -years flood flow, although the results for 50 and 100 years flood are mentioned parallelly.

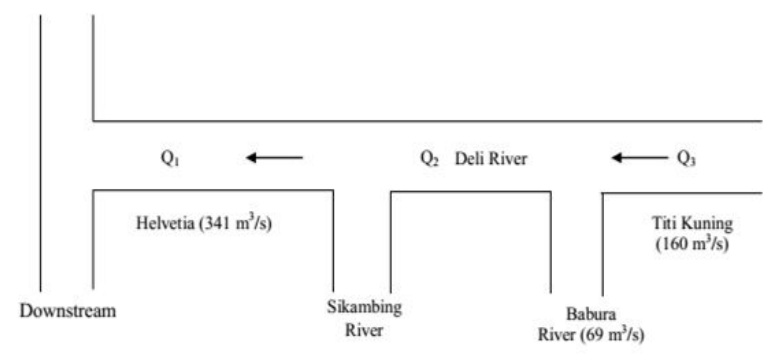

Fig. 2. Sketch of the capacity of the Deli River (JICA, 1992)

Table 1. Computed discharges for Deli River (JICA, 1992)

\begin{tabular}{|c|c|c|c|c|c|}
\hline \multirow{2}{*}{$\begin{array}{c}\text { Flood flow } \\
\left(\mathrm{m}^{3} / \mathrm{s}\right)\end{array}$} & \multicolumn{5}{|c|}{ Return period (years) } \\
\cline { 2 - 6 } & 10 & 20 & 30 & 50 & 100 \\
\hline $\mathrm{Q}_{1}$ & 460 & 530 & 570 & 620 & 690 \\
\hline $\mathrm{Q}_{2}$ & 420 & 490 & 520 & 570 & 640 \\
\hline $\mathrm{Q}_{3}$ & 260 & 300 & 320 & 340 & 380 \\
\hline
\end{tabular}

\section{Methodology}

The watersheds under study are the Belawan River basin and the Deli River basin as shown in Figure 1. Both rivers are important components of the well being of Medan City since they flow through the middle of the city. The main inputs in the process of this study are the rainfall data, the river profiles, and the watersheds. The rainfall data consist of dayly maximum rainfall for 10 years from 2004 until 2013 obtained from 3 rainfall stations, one located in the upstream, one in the middle of the city, and the other in the downstream. Based on these rain fall data,the maximum dayly precipitation of certain return periods can be calculated.

From the maximum dayly precipitation and the characteristics of the watersheds, the floods of certain return periods can be computed. Next using HEC-RAS with the inputs of recurrence flood discharge, the cross and the longitudinal river profiles, and the watershed characters represented by the runoff coefficient, the water profile can be simulated to gain the spatial coverage of the inundation area for certain return periods of floods.

The resulting flood maps are then to be stacked on top of maps of Medan City in Gis layers. However, prior to the overlaying process, all layers of information should be preparedon the same coordinate system. Within the GIS framework, the houses and infrastructures affected in the inundation area can be identified. Afterward, the damage cost due to certain periods of floods can be computed using a simple formula. Figure 3 describes the scope and steps of the study in a schematic way. To simplify the process, we will demonstrate the results computed for the Babura River which is a tributary of the Deli River with frequent flooding [8]. The process could be continued for the whole rivers involved using the same procedure, and the total estimated damage cost is given. 


\section{Results and Analysis}

\subsection{River Hydrology}

Based on the maximum daily rainfall data for 10 years, hourly rainfall intesity, and the runoff coefficient representing the landuse of the watersheds, the maximum discharge of certain return periods were predicted using the method of the Nakayasu synthetic unit hydrograph method. The resulting discharges for $2,3,5,10,25,50$ and 100 years recurrence intervals are tabulated in Table 2. It can be seen from the table that the flood magnitude of the Deli River is almost twice as large as that of the Belawan river for a same return period. Also, the Deli River's flood values given in Table 2 are relatively larger than that given in Table 1, as the watersheds have experienced landuse change and deforestation over the years. Note that the Babura River, a tributary of the Deli River, is included in Table 2 because the examples shown in this study are given from the calculation of the Babura River.

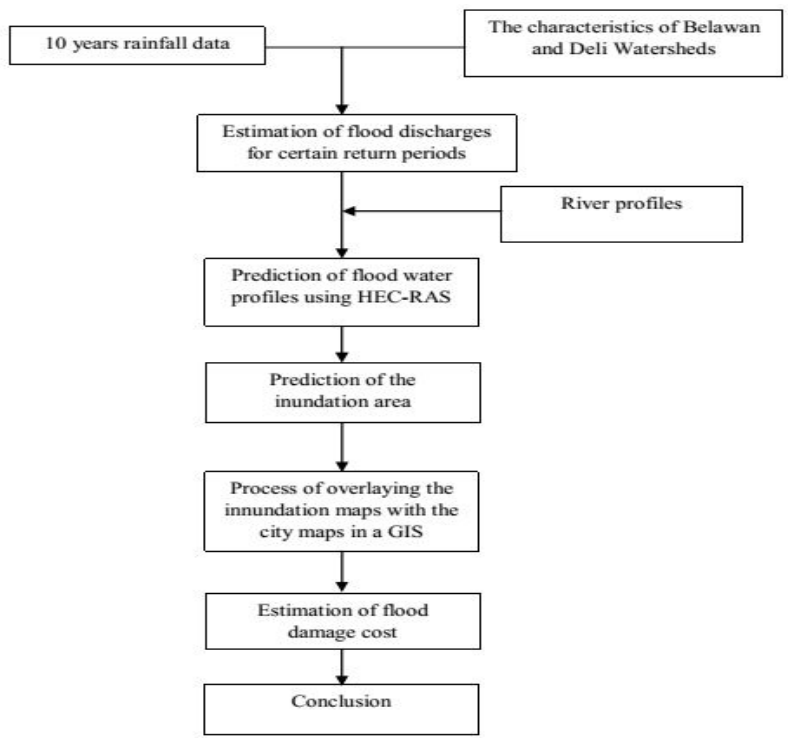

Fig. 3. The scope and the steps of the study

Table 2: Estimation of flood discharge for certain return periods

\begin{tabular}{|c|c|c|c|c|c|c|c|c|}
\hline \multirow{3}{*}{ Deli River } & maximum flood flow & \multicolumn{7}{|c|}{ return period (years) } \\
\hline & Q maximum & 2 & 3 & 5 & 10 & 25 & 50 & 100 \\
\hline & $\left(\mathrm{m}^{3} / \mathrm{s}\right)$ & 401 & 453 & 510 & 582 & 674 & 741 & 809 \\
\hline \multirow{3}{*}{ Babura River } & maximum flood flow & \multicolumn{7}{|c|}{ return period (years) } \\
\hline & Q maximum & 2 & 3 & 5 & 10 & 25 & 50 & 100 \\
\hline & $\left(\mathrm{m}^{3} / \mathrm{s}\right)$ & 100 & 118 & 141 & 174 & 221 & 262 & 307 \\
\hline \multirow{3}{*}{ Belawan River } & maximum flood flow & \multicolumn{7}{|c|}{ return period (years) } \\
\hline & Q maximum & 2 & 3 & 5 & 10 & 25 & 50 & 100 \\
\hline & $\left(\mathrm{m}^{3} / \mathrm{s}\right)$ & 236 & 258 & 283 & 314 & 353 & 382 & 411 \\
\hline
\end{tabular}

\subsection{Surface Water Profiles}

The flood values in Table 2 are used in HEC-RAS 4.0 to estimate the surface water profiles with reference to the associated return periods [13]. The larger is the return period, 
the deeper is the water depth at the river bank as well as the farther is the flood distance from the river bank. For example,

Figure 4 shows the 25-year water profile at a cross section in the Babura River. It can be seen from the figure that the water depth reaches about $2 \mathrm{~m}$ at the river bank and the flood distance reaches about $100 \mathrm{~m}$ to the left and $100 \mathrm{~m}$ to the right from the center of the river. The figures like that shown in Figure 5 were obtained using HEC-RAS 4.0 for all available data of the cross profiles of theBelawan and Deli river channels. Figure 5 shows the resulting flood map of the Babura River for the 25-years return period.

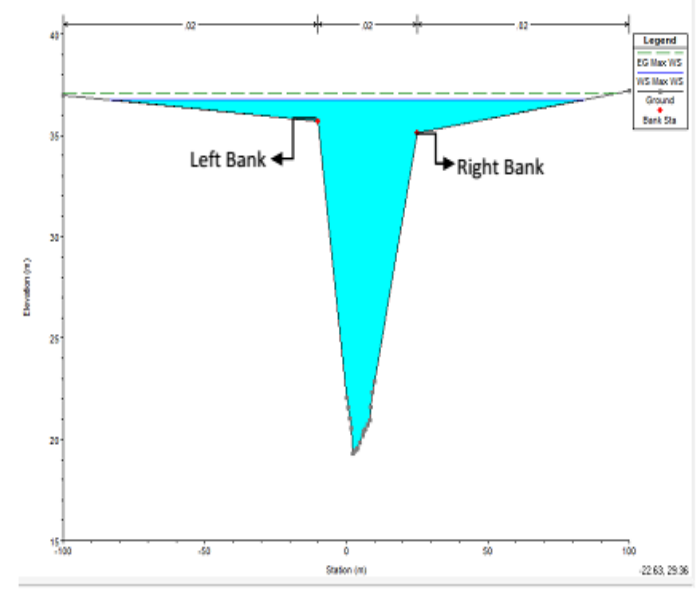

Fig. 4. 25 years water profile at a cross section in the Babura River, a tributary of the Deli River

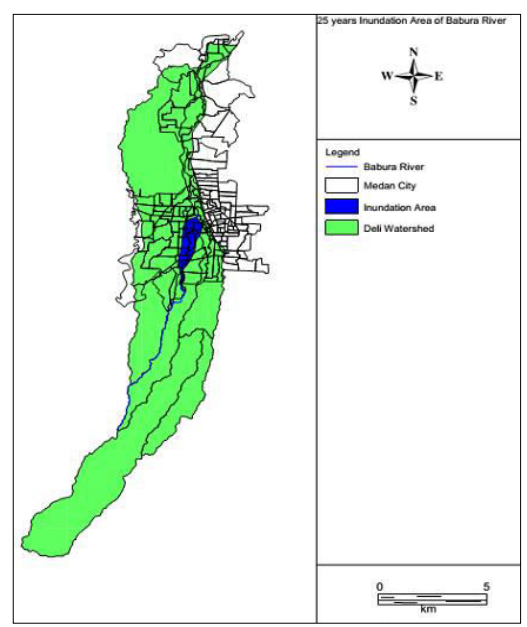

Fig. 5. The resulting 25 -years flood map computed for the Babura River

\subsection{Inundation Areas in a GIS Framework}

To evaluate the extent of the inundation area, the resulting map of Figure 5 was stacked on top of city maps in GIS layers. Figure 6 shows the inundation area of the Babura River for the 25 years flood in GIS layers. The layer of the administrative areas of Medan City's subdistricts is included in the figure as a basis for the damage estimation. There are 7 affected subdistricts within 3 districts including, written consecutively from the upper to the 
lower stream, 1) Padang Bulan and 2) Darat subdistricts in the Medan Baru district, 3) Madras Hulu, 4) Polonia and 5) Angrung in the Medan Polonia district, and 6) Petisah Hulu and 7) Petisah Tengah in the Medan Petisah district. The figures like Figure 6 could be obtained using the same method for the whole Belawan and the Deli Rivers.

\subsection{Estimation of Flood Induced Damage Cost}

To estimate the number of people affected by the flood in a subdistrict, a simple proportionality formula is used as follows.

$$
\text { Number of people affected }=\frac{\text { Inundation area }}{\text { Total area }} \times \text { Total population }
$$

Along the Babura River there are a total of 13287 people affected by the 25 -years flood. The calculation for each subdistrict is given in Table 3 . To estimate the number of houses affected by the flood in a subdistrict, a similar formula is used as follows

$$
\text { Number of houses affected }=\frac{\text { Inundationarea }}{\text { Totalarea }} x \text { Totalhouses }
$$

Along the Babura River there are a total of 3128 houses affected by the 25 -years flood. The calculation for each subdistrict is given in Table 4 .

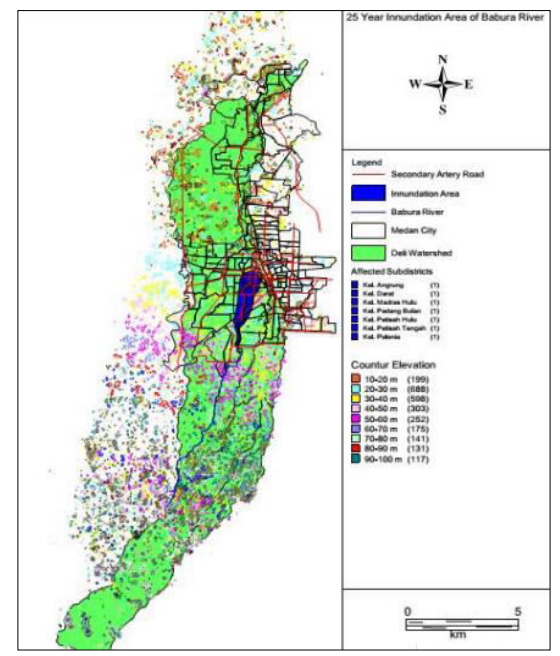

Fig. 6. The 25 years inundation area of the Babura River in a GIS format

Table 3: Calculation of the affected people by the 25-years flood for the Babura River

\begin{tabular}{|c|c|c|c|c|c|}
\hline Districts & Subdistricts & Area $\left(\mathrm{km}^{2}\right)$ & Inundation area $\left(\mathrm{km}^{2}\right)$ & Population & Number of people affected \\
\hline Medan Baru & Padang Bulan & 0.66 & 0.06 & 9123 & 829 \\
\hline Medan Baru & Darat & 0.16 & 0.04 & 1911 & 478 \\
\hline Medan Polonia & Madras Hulu & 0.31 & 0.09 & 2785 & 809 \\
\hline Medan Polonia & Polonia & 0.52 & 0.18 & 17392 & 6020 \\
\hline Medan Polonia & Angrung & 0.12 & 0.03 & 1729 & 432 \\
\hline Medan Petisah & Petisah Hulu & 0.27 & 0.08 & 4711 & 1396 \\
\hline Medan Petisah & Petisah Tengah & 0.55 & 0.2 & 9137 & 3323 \\
\hline \multicolumn{2}{|c|}{ Total } & 2.59 & 0.68 & 46788 & 13287 \\
\hline
\end{tabular}


Table 4: Calculation of the affected houses by the 25-years flood for the Babura River

\begin{tabular}{|c|c|c|c|c|c|}
\hline Districts & Subdistricts & Area $\left(\mathrm{km}^{2}\right)$ & Inundation area $\left(\mathrm{km}^{2}\right)$ & Houses (unit) & Number of houses affected (unit) \\
\hline Medan Baru & Padang Bulan & 0.66 & 0.06 & 4457 & 405 \\
\hline Medan Baru & Darat & 0.16 & 0.04 & 606 & 152 \\
\hline Medan Polonia & Madras Hulu & 0.31 & 0.09 & 961 & 279 \\
\hline Medan Polonia & Polonia & 0.52 & 0.18 & 2498 & 865 \\
\hline Medan Polonia & Angrung & 0.12 & 0.03 & 428 & 107 \\
\hline Medan Petisah & Petisah Hulu & 0.27 & 0.08 & 788 & 233 \\
\hline Medan Petisah & Petisah Tengah & 0.55 & 0.2 & 2990 & 1087 \\
\hline \multicolumn{2}{|l|}{ Total } & 2.59 & 0.68 & 12728 & 3128 \\
\hline
\end{tabular}

To estimate the flood damage cost for houses, a standard suggested by The National Development Planning Agency, Republic of Indonesiawas used as a reference [5] Table 5 lists the standard which is modified to account for inflation. For simplicity, the standard cost for moderate damage was used to calculate the damage cost using the following simple formula.

It is found that the damage cost for the 25 year flood of the Babura River was Rp $62,562,566,693$. The calculation for each subdistrict is given in Table 6. Using the same procedure, the people and houses affected, as well as the damage cost can be estimated for the whole segments of the Belawan and Deli Rivers.

\section{The damage cost $=$ the number of houses affected $\mathrm{x}$ the standard cost}

Table 5: A standard to estimate the flood damage cost

\begin{tabular}{|c|c|c|}
\hline No & Name of main roads & Level of inundation \\
\hline 1 & Jl. Djamin Ginting & Moderate \\
\hline 2 & Jl.Dr Mansyur & Severe \\
\hline 3 & Jl. Pattimura & Severe \\
\hline
\end{tabular}

Table 6: Calculation of the damage cost caused by the 25 years flood of the Babura River

\begin{tabular}{|c|c|c|c|c|c|c|}
\hline Distrits & Suldistrits & Area $\left(\mathrm{km}^{2}\right.$ & Inundation area $\left(\mathrm{km}^{2}\right)$ & Houses (unit) & Number of howses affected (uri) & Estimated flood damage cost (Rp) \\
\hline Medan Baru & Padang Buan & 0.66 & 0.06 & 457 & 405 & $8,103,636,364,00$ \\
\hline Medan Baru & \begin{tabular}{|l|} 
Darat \\
\end{tabular} & 0.16 & 0.04 & 606 & 152 & $3,030,000,000,00$ \\
\hline Medan Pobonia & Madras Huh & 0.31 & 0.09 & 961 & 279 & $5,580,000,000.00$ \\
\hline Medan Pobnin & Polbrin & 0.52 & 0.18 & 2498 & 865 & $17,293,446,154,00$ \\
\hline Medan Pobaia & Angrung & 0.12 & 0.03 & 428 & 107 & $2,140,000,000.00$ \\
\hline Medan Petisah & Petisah Hulu & 0.27 & 0.08 & 788 & 233 & $4,669,629,630,00$ \\
\hline Medan Petisah & Petisah Tengah & 0.55 & 0.2 & 2990 & 1087 & $21,745,45,4,45,00$ \\
\hline $\mathrm{Tot}$ & & 2.59 & 0.68 & 12728 & 3128 & $625625,56,693,00$ \\
\hline
\end{tabular}

Figure 7.a shows the flood map layer of the Babura River stacked on top of the important public buildings layer. Based on these layers of GIS, the number and type of important building saffected could be indentified as shown in Table 7.

Table 7: The important buildings affected by the 25-years flood of the Babura River

\begin{tabular}{|c|c|c|c|c|c|c|c|c|c|}
\hline Districts & Subdistricts & Hotd & Restairnt & Gas Station & Mall & Hospital & Junior High School & Semior High School & Primary High School \\
\hline Medan Baru & Padang Bulan & 0 & 0 & 0 & 0 & 1 & 0 & 0 & 3 \\
\hline Medan Baru & Darat & 0 & 0 & 0 & 0 & 0 & 0 & 1 & 0 \\
\hline Madan Pobecia & Madras Hulu & 0 & 2 & 0 & 0 & 0 & 1 & 0 & 0 \\
\hline Modan Pobocia & Polonia & 0 & 8 & 0 & 0 & 1 & 2 & 2 & 7 \\
\hline Modan Pobonia & Angning & 0 & 4 & 0 & 0 & 0 & 1 & 1 & 4 \\
\hline Medan Petisah & Petisah Hulu & 0 & 0 & 0 & 0 & 0 & 0 & 0 & 2 \\
\hline Median Petisah & Petisah Tengah & 0 & 0 & 0 & 0 & 0 & 0 & 0 & 0 \\
\hline \multicolumn{2}{|c|}{ Total } & 0 & 14 & 0 & 0 & 2 & 4 & 4 & 16 \\
\hline
\end{tabular}


Figure 7.b shows the flood map layer of the Babura River stacked on top of the road layer. Based on these layers of GIS, the main roads affected could be indentified as shown in Table 8 including the area of Polonia Airport.

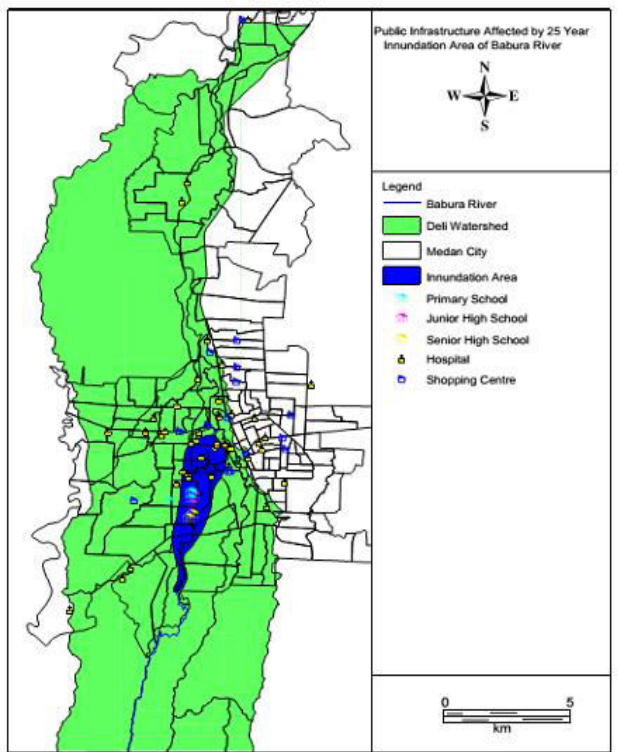

a. Flood map and public infrastructure

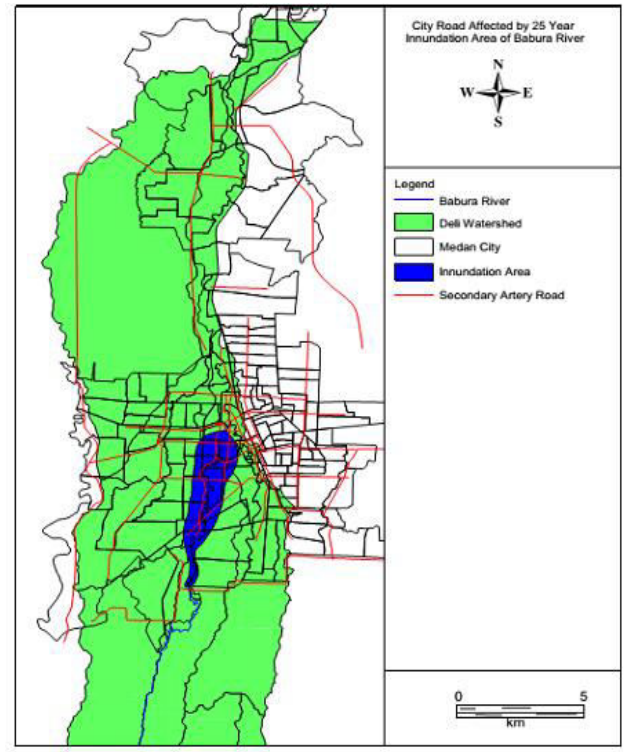

b. Flood map versus the city roads

Fig. 7. The GIS layers of flood map

Table 8: The main roads affected by the 25-years flood of the Babura River

\begin{tabular}{|c|c|c|}
\hline No & Name of main roads & Level of inundation \\
\hline 1 & Jl. Djamin Ginting & Moderate \\
\hline 2 & Jl.Dr Mansyur & Severe \\
\hline 3 & Jl. Pattimura & Severe \\
\hline
\end{tabular}

Using the same procedure, the public infrastructures affected, including the roads and the transportation facilities, can be estimated for the whole rivers in the watersheds of Belawan and Deli. Figure 8 depicts the flood map for the whole rivers in the basins. Meanwhile, Table 9 tabulates the damage costs estimated for the Belawan and the Deli Rivers, which includes the Babura River, for 25, 50, and 100 years flood. It can be seen from Table 10 that the damage caused by the Belawan River is the least compared with that by the other rivers, whereas the Deli River causes the most damage. This is due to the fact that Deli River discharges comparatively a larger flood magnitude for the same return period and it flows right toward the center of the city where the population is mostly dense. 
Table 9: Damage costs estimated for the Belawan River and Deli River for different return periods

\begin{tabular}{|c|c|c|c|c|}
\hline \multirow{2}{*}{ River } & Retum period & Number of people affected & Number of houses affected & Estimated flood damage cost \\
\cline { 2 - 5 } & (Years) & (People) & (Unit) & (Rp) \\
\hline \hline \multirow{3}{*}{ Deli River } & 25 & 28755 & 7803 & $156,055,718,288.00$ \\
\cline { 2 - 5 } & 50 & 50434 & 13110 & $262,194,839,180.00$ \\
\cline { 2 - 5 } & 100 & 219658 & 42336 & $846,750,183,208.00$ \\
\hline \hline \multirow{3}{*}{ Babura River } & 25 & 13287 & 3128 & $62,562,566,693,00$ \\
\cline { 2 - 5 } & 50 & 32856 & 7064 & $141,279,006,406.00$ \\
\cline { 2 - 5 } & 100 & 60711 & 13508 & $270,150,698,007.00$ \\
\hline \hline \multirow{3}{*}{ Belawan River } & 25 & 2751 & 528 & $10,556,879,257.00$ \\
\cline { 2 - 5 } & 50 & 3009 & 1102 & $41,940,235,294,00$ \\
\cline { 2 - 5 } & 100 & 64569 & 8909 & \\
\hline
\end{tabular}

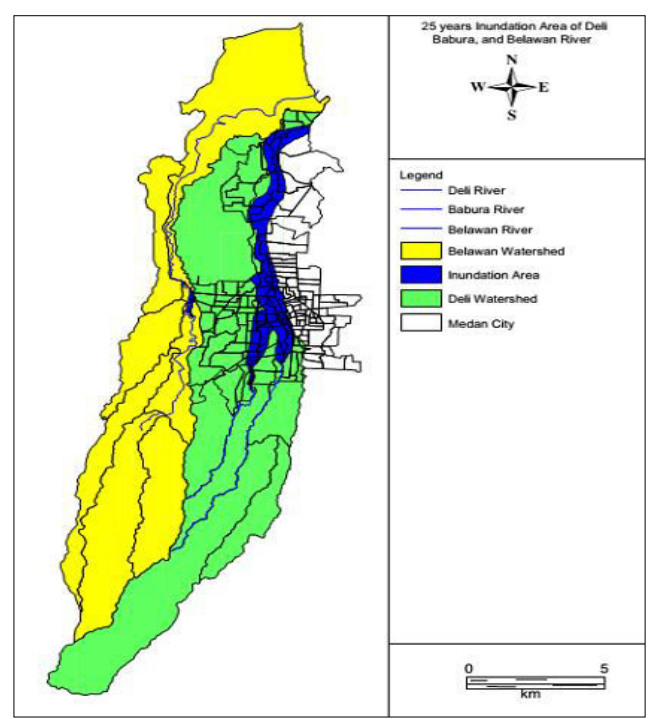

Fig. 8. Flood map of Belawan and Deli watersheds for 25 years flood

\section{Conclusion}

Based on the rainfall and the watersheds data, we have attempted to estimate the flood discharges of the main rivers in Medan City for certain return periods. It is found that the discharges estimated in this study are comparatively larger than that reported in a study supported by JICA (1992). Using HEC-RAS the flood discharges together with the river profiles and the runoff coefficient are inputted to obtain the flood maps. By stacking the resulting flood maps on top of city map and infrastructure layers, we are able to identify the extent of the inundation and estimate the affected people and houses as well as the ensuing damage cost. Also, the affected public infrastructures can be identified and categorized. Note that we demonstrated the results for 25 year flood of the Babura River which is a tributary of the Deli River. The same procedures could be conducted for all floods of the rivers within the basins for different return periods. 


\section{Acknowledgment}

This study was supported by The Ministry of Reasearch, Technology, and Higher

Education of Indonesia through the Research Scheme of "Hibah Bersaing" in 2015-2016.

\section{References}

1. T.V Cech, Principles of Water Resources History, Development, Management, and Policy. Second Edition. Wiley. USA (2005)

2. Freier. Principle of Water Resources: History, Development, Management and Policy in GIS Flooding, New Jersey (2005)

3. M Ginting, Studi Potensi dan Mitigasi Banjir Kota Medan. Prosiding Seminar Nasional-1 BMPTTSSI USU, Medan. (2012)

4. G.M. Hasibuan, Model koordinasi kelembagaan pengelolaan banjir perkotaan terpadu. Disertasi Perencanaan Wilayah USU. Medan (2004)

5. http//www.scribd.com/doc/Bappena, Laporan Penilaian Kerusakan Kerugian Jabodetabek. (2007)

6. JICA, Main Report,. The Study on Belawan Padang Integrated River Basin Development, Medan (1992)

7. J. Kodoatie, Tata Ruang Air, On Integrated Water Resource Management in Indonesia. Penerbit Andi (2005)

8. Kurniawan, A.. Analisis Debit Banjir Rancangan Sungai Babura di Hilir Kawasan Kampus USU. Bidang Studi Teknik Sumber Daya Air USU, Medan (2012)

9. Lyon, Gis for Water Resources and Watershed Management. London (2003)

10. N. Muhadi, and Abdullah, A.F. Flood Damage Assessment in Agricultural Area in Selangor River Basin. Jurnal Teknologi (Sciences \& Engineering) 76:15 (2015) 111117.

11. D. Pasaribu,. Konsep Pengelolaan Drainase Kota Medan. Tesis Master, Program S2 Teknik Sipil USU (2007)

12. K. Trihono, Penerapan Sistem Informasi Geografis dalam untuk Mereduksi Kerugian Akibat Banjir. Seminar Nasional Aplikasi Teknologi Informasi (SNATI), Yogyakarta (2007)

13. U.S Army Corps of Engineers - Hydrologic Engineering Center (HEC). Hydraulic Reference Manual HEC-RAS 3.1.3. California: U.S. Army Corps of Engineers (2001)

14. A. Zevri, Analisis Potensi Resiko Banjir pada DAS yang Mencakup Kota Medan dengan Sistem Informasi Geografis. Tesis Master Prodi S2 Teknik Sipil USU (2014). 